Brit. Heart J., 1965, 27, 756.

\title{
CHROMOSOME STUDIES IN 156 PATIENTS WITH CONGENITAL HEART DISEASE
}

\author{
BY \\ JANET M. ANDERS, ELIZABETH C. MOORES, AND RICHARD EMANUEL
}

From The Institute of Cardiology and National Heart Hospital, London W.1

Received February 26, 1965

\begin{abstract}
Abnormal chromosomes are present in Down's syndrome, where the incidence of congenital heart disease varies from 22 to 38 per cent (Kaiser and Schmid, 1952; Rowe and Uchida, 1961) and in Turner's syndrome, which may be complicated by coarctation of the aorta (Polani, Hunter, and Lennox, 1954) and pulmonary valve stenosis (Rainier-Pope et al., 1964). In the rare trisomic syndromes involving chromosomes 13-15 and 17-18 the frequency of ventricular septal defect and persistent ductus arteriosus has been noted (Townes et al., 1963; Smith et al., 1963). In addition persistent ductus arteriosus was found in 3 of the 10 cases of XXXXY sex chromosomes reviewed by Joseph, Anders, and Taylor (1964). Chromosome abnormalities have also been reported in patients with uncomplicated atrial septal defects and other forms of congenital heart disease (Böök, Santesson, and Zetterqvist, 1961; Sasaki, Makino, and Kajii, 1963). It was this background that prompted us to examine the chromosomes in patients with isolated congenital heart disease. Cases in which the cardiac lesion was associated with Down's and Turner's syndromes were excluded as the cytogenetic abnormalities of these syndromes have already been described.
\end{abstract}

\section{SubJECTS AND MeThoD}

The material examined was obtained from 156 patients with congenital heart disease (Table I). The diagnosis in these patients was confirmed anatomically (operation or necropsy) in 82, by angiocardiography and/or cardiac catheterization in 66, and by clinical, electrocardiographic, and radiological examination alone in 8 . Their ages varied from 3 months to 67 years. The distribution within this age range is shown in Fig. 1.

Congenital heart disease was familial in 22 patients, representing 14 different families. In 18 instances the defect in the relative was the same as in the propositus.

Chromosome preparations were obtained from leucocyte cultures in all cases. Blood for these studies was collected either by venepuncture or during cardiac catheterization. The technique used for culture was a modification of that described by Moorhead et al. (1960). Details of the modification are described elsewhere (Anders, Moores, and Emmanuel, 1965).

A minimum of 25 cells from each patient was studied under the microscope except in three cases where the technical quality of the preparations was poor, and only 12,13 , and 15 suitable cells, respectively, were found. One representative karyotype was prepared from each patient, except where further confirmation of results was required.

\section{RESULTS}

No major chromosome abnormality was found. In all patients studied the modal number was 46. The total counts for each age-group with percentages of hypo- and hypermodal cells is given in Table II. The increase of hypomodal cells with advancing age was similar to that reported by Jacobs et al. (1963) in a group of 247 people with normal karyotypes. 
TABLE I

Analysis of Congenital Heart Disease in 156 Patients Studied

\begin{tabular}{|c|c|c|}
\hline Atrial septal defect (secundum) & $\begin{array}{l}\text { Uncomplicated } \\
\text { Familial } \\
\text { With mitral valve disease } \\
\text { With skeletal deformity of upper limbs }\end{array}$ & $\left.\begin{array}{r}14 \\
14 \\
2 \\
2\end{array}\right\} 32$ \\
\hline Atrio-ventricular defects* & $\begin{array}{l}\text { Uncomplicated } \\
\text { Familial } \\
\text { With pulmonary valve stenosis } \\
\text { With syndactyly } \\
\text { With coarctation of aorta } \\
\text { With secundum ASD }\end{array}$ & $\left.\begin{array}{r}14 \\
3 \\
2 \\
1 \\
1 \\
1\end{array}\right\} 22$ \\
\hline Ventricular septal defect & $\begin{array}{l}\text { Uncomplicated } \\
\text { Familial } \\
\text { With multiple skeletal deformities }\end{array}$ & $\left.\begin{array}{r}15 \\
1 \\
1\end{array}\right\} 17$ \\
\hline Fallot's tetralogy & $\begin{array}{l}\text { Uncomplicated } \\
\text { With patent ductus arteriosus }\end{array}$ & $12\} 13$ \\
\hline Pulmonary valve stenosis & $\begin{array}{l}\text { Uncomplicated } \\
\text { With dextrocardia }\end{array}$ & $\left.\begin{array}{r}14 \\
1\end{array}\right\} 15$ \\
\hline Coarctation & $\begin{array}{l}\text { Uncomplicated } \\
\text { With aortic valve disease }\end{array}$ & $\left.\begin{array}{l}6 \\
4\end{array}\right\} 10$ \\
\hline Patent ductus arteriosus & $\begin{array}{l}\text { Uncomplicated } \\
\text { Familial }\end{array}$ & $\left.\begin{array}{l}7 \\
3\end{array}\right\} 10$ \\
\hline Aortic valve stenosis & Uncomplicated & 10 \\
\hline $\begin{array}{l}\text { Hypertrophic obstructive } \\
\text { cardiomyopathy }\end{array}$ & $\begin{array}{l}\text { Uncomplicated } \\
\text { Familial }\end{array}$ & $\left.\begin{array}{l}1 \\
1\end{array}\right\} 2$ \\
\hline Supravalve aortic stenosis & & 1 \\
\hline Other lesions & $\begin{array}{l}\text { Transposition (1) Corrected transposition (4) } \\
\text { Primary pulmonary hypertension } \\
\text { Eisenmenger PDA (3) VSD (1) } \\
\text { VSD with double outflow RV } \\
\text { Ebstein's disease } \\
\text { Dextrocardia (complex) } \\
\text { Pulmonary atresia } \\
\text { Anomalous coronary artery } \\
\text { Two-chambered right ventricle } \\
\text { Cor triatriatum } \\
\text { Isolated lævocardia }\end{array}$ & $\begin{array}{l}5 \\
3 \\
4 \\
2 \\
2 \\
3 \\
1 \\
1 \\
1 \\
1 \\
1\end{array}$ \\
\hline Total $\ldots$ & $\cdots$ & 156 \\
\hline
\end{tabular}

* Atrio-ventricular defects include simple ostium primum, partial atrio-ventricular canal, and complete atrio-ventricular canal.

TABLE II

Distribution of Chromosome Counts in Relation to Age

\begin{tabular}{|c|c|c|c|c|c|c|c|c|c|}
\hline \multirow[t]{2}{*}{ Age-group } & \multirow{2}{*}{$\begin{array}{l}\text { No. of } \\
\text { patients }\end{array}$} & \multicolumn{6}{|c|}{ Chromosome counts } & \multirow{2}{*}{$\begin{array}{l}\text { Per cent } \\
\text { hypomodal } \\
\text { cells }\end{array}$} & \multirow{2}{*}{$\begin{array}{c}\text { Per cent } \\
\text { hypermoda } \\
\text { cells }\end{array}$} \\
\hline & & $<45$ & 45 & 46 & 47 & $>47$ & Total & & \\
\hline $\begin{array}{r}0-14 \\
15-29 \\
30-70\end{array}$ & $\begin{array}{l}46 \\
70 \\
40\end{array}$ & $\begin{array}{r}7 \\
27 \\
13\end{array}$ & $\begin{array}{l}13 \\
30 \\
45\end{array}$ & $\begin{array}{l}1149 \\
1982 \\
1104\end{array}$ & $\begin{array}{r}7 \\
21 \\
8\end{array}$ & $\begin{array}{l}0 \\
3 \\
0\end{array}$ & $\begin{array}{l}1176 \\
2063 \\
1170\end{array}$ & $\begin{array}{l}1 \cdot 70 \\
2 \cdot 76 \\
4 \cdot 96\end{array}$ & $\begin{array}{l}0.60 \\
1 \cdot 16 \\
0.68\end{array}$ \\
\hline Total & 156 & 47 & 88 & 4235 & 36 & 3 & 4409 & 3.06 & 0.86 \\
\hline
\end{tabular}




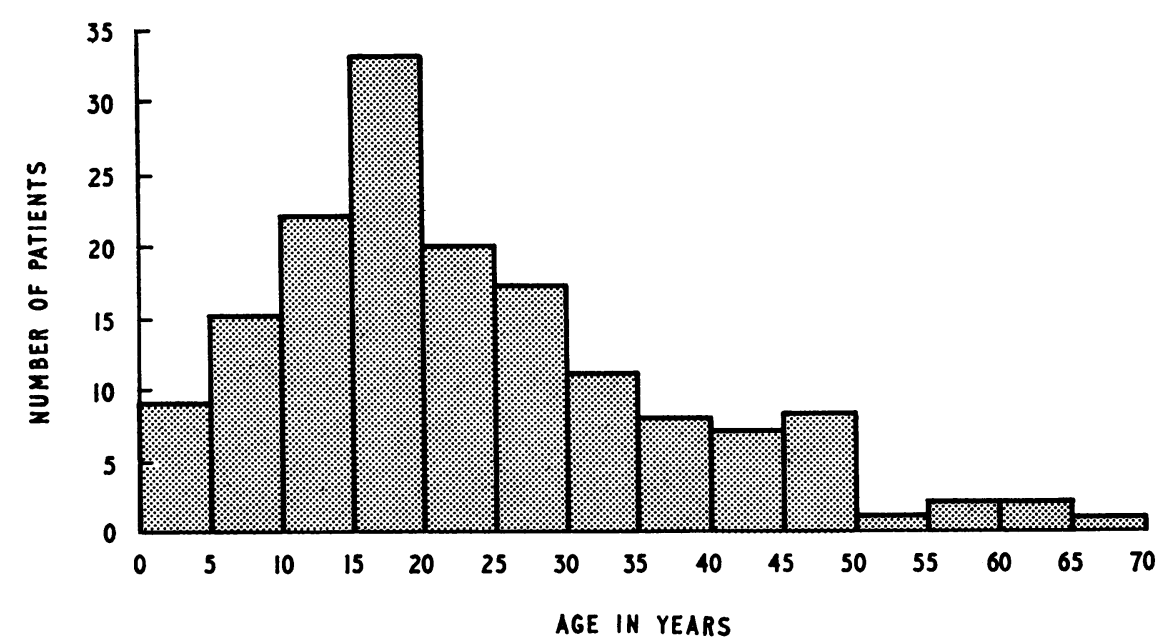

FIG. 1.-Age distribution of the 156 patients with congenital heart disease studied.

In 15 of the 4409 cells examined dicentric or ring chromosomes were found. These included 10 cells with dicentrics and 5 with rings, and they occurred in 9 of the 156 patients studied.

Variation in size of certain chromosomes was observed: this was particularly marked in pair 16 but was only recorded if one 16 was either as large as a 12 or resembled a 19 . This degree of variation was found in four patients, and the clinical details are given in Table III. In two of these (A.T. and Y.S.), the unusual 16 was similar in length to a number 12 (Fig. 2 and 3). The increased length was apparently due to the elongation of the secondary constriction normally found in the paracentric region of the long arms. The characteristic appearance produced by the parallel nature of this secondary constriction enabled the chromosome to be distinguished in the great majority of cells. Family studies are in progress on A.T. and Y.S., and all three sibs of A.T. show a similar long 16 (Fig. 3); both the sibs so far examined clinically have normal hearts. In the other two patients (J.M. and M.W.) the majority of cells showed one 16 shorter than usual and in extreme instances it resembled a 19 (Fig. 4). This variation, however, was not well defined but we have recorded it for comparison with other published work. In all four patients the short arms of pair 16 were apparently normal.

The only other variation of note occurred in one patient (S.L., clinical details in Table III) in whom the short arms of one chromosome 15 were longer than usual. In good quality cells, an additional secondary constriction could be seen between the usual constriction adjacent to the

TABLE III

Types of Congenital Heart Disease Present in Five Patients with Chromosome Variations

\begin{tabular}{|c|c|c|c|c|}
\hline Patient & $\begin{array}{l}\text { Age } \\
\text { (yr.) }\end{array}$ & Sex & $\begin{array}{c}\text { Chromosome } \\
\text { variation }\end{array}$ & Cardiac lesion \\
\hline $\begin{array}{l}\text { Y.S. } \\
\text { A.T. }\end{array}$ & $\begin{array}{l}12 \\
39\end{array}$ & $\begin{array}{l}\mathbf{F} \\
\mathbf{M}\end{array}$ & $\begin{array}{l}\text { Long } 16 \\
\text { Long } 16\end{array}$ & \multirow{3}{*}{$\begin{array}{l}\text { Persistent ductus arteriosus } \\
\text { Complete atrio-ventricular canal with pulmonary valve } \\
\text { stenosis } \\
\text { Ostium primum atrial septal defect with coarctation of } \\
\text { aorta } \\
\text { Ostium primum atrial septal defect } \\
\text { Coarctation of aorta }\end{array}$} \\
\hline J.M. & 12 & $\mathbf{M}$ & Short 16 & \\
\hline $\begin{array}{l}\text { M.W. } \\
\text { S.L. }\end{array}$ & $\begin{array}{l}22 \\
10\end{array}$ & $\begin{array}{l}\mathbf{M} \\
\mathbf{M}\end{array}$ & $\begin{array}{l}\text { Short } 16 \\
\text { Unusual } 15\end{array}$ & \\
\hline
\end{tabular}




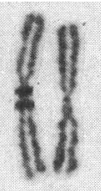

I

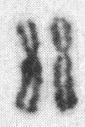

6
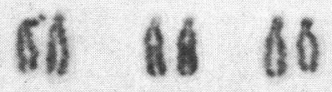

13

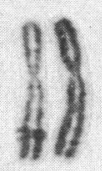

2

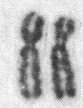

7
$14 \quad 15$

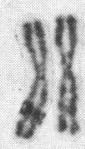

3

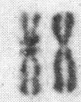

8

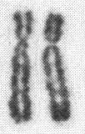

4

5
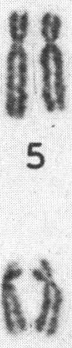

12

$x$

8:8

$8 x$

da

$8 \times 88$

16

17

18

$19 \quad 20$

$\begin{array}{lll}\text { y } & \text { An } & 1 \pi \\ 41 & 22\end{array}$

Fig. 2.-Karyotype of A.T. showing increased length of one chromosome 16.

Y.S.
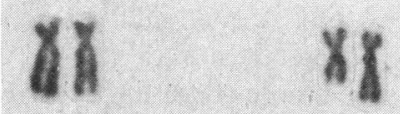

$\lambda x$

84

A.T.

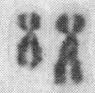

ถัด

ถ⿱亠乂

Sib 1
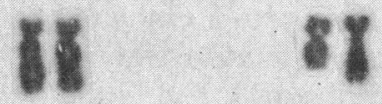

มู

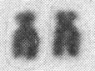

Sib 2

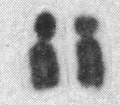

รกี

i)

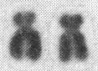

Sib 3

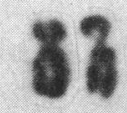

มנ
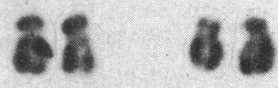

12

16

17

18

FIG. 3.-The long 16 in Y.S., A.T., and the three sibs of A.T., showing the similarity of this chromosome in all five cases, and its length in relation to a normal 12. 


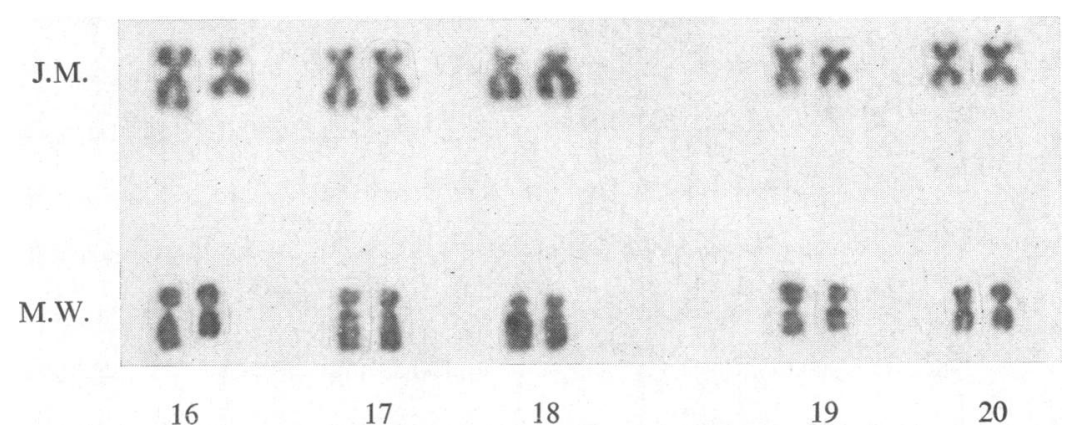

FIG. 4.-Comparison of the short 16 in J.M. and M.W., showing the similarity to a normal 19.

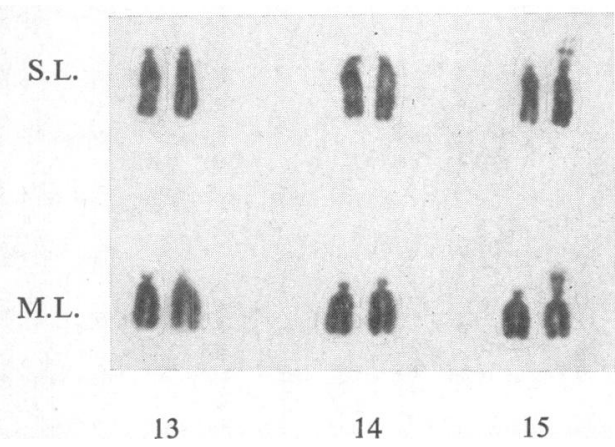

Fig. 5.-The additional secondary constriction and normal satellites of chromosome 15 from S.L. and his mother, M.L. satellites and the centromere (Fig. 5). The parents of this patient have also been examined, and the mother (M.L.) showed a similar chromosome 15 (Fig. 5).

\section{DisCUSSION}

Variation in individual chromosomes occurred most frequently in pair 16. W. M. Court Brown (1964, personal communication), from an extensive study of normal subjects, has suggested that the polymorphism characteristic of this pair includes variation in size between a 13 and a 19. We have accepted this range in the present study.

In two of our patients one chromosome 16 was outside these limits (Fig. 2 and 3). One of these patients had an atrio-ventricular defect complicated by pulmonary stenosis (A.T.), the other had an uncomplicated persistent ductus arteriosus (Y.S.). This variant, however, is not confined to congenital heart disease, as a similar chromosome has been reported in 4 out of a total of 627 normal cases studied by Jacobs, Brunton, and Court Brown (1964), and Court Brown (personal communication). In addition a comparable 16 has been described in cases of schizophrenia: an XY/XXY father and his daughter were reported by Court Brown et al. (1964), and one other instance was noted in 54 female schizophrenics studied by Jagiello and Anders (1965). Finally Jennings and Turner (1961) and Carr (1963) have described one case each, with a similar 16 associated with multiple congenital anomalies, though the hearts in these cases were apparently normal. This distinctive 16 can be an inherited character as shown by the three sibs of A.T. and the father and daughter reported by Court Brown et al. The similar morphology of this chromosome in all the cases discussed was remarkable.

The two patients with a small 16 both had an ostium primum atrial septal defect, one complicated by coarctation of the aorta (J.M.) and the other by polydactyly (M.W.). The size of the small 16 was variable in each case and we considered that this was not a clearly defined characteristic. A similar variation has been reported by Sasaki et al. (1963) in 9 out of 22 patients with congenital heart disease. Three of these had an ostium secundum atrial septal defect, two had atrial and ventricular septal defects combined, one had an unspecified atrial septal defect, and 3 had congenital heart disease of unknown type. Although a noticeably small 16 has been recorded most frequently in cases with defects of the atrial septum, this variation falls within the normal range suggested by Court Brown. 
The other morphological variation of note occurred in a boy (S.L.) with coarctation of the aorta. Both he and his mother (M.L.) had a chromosome 15 with unusually long short arms (Fig. 5), similar to those reported by Jacobs et al. (1964) in one of their normal cases. Chandra and Hungerford (1963) observed a variation of this with only terminal satellites in a normal father and daughter, and Jacobs et al. found a further variant in their study of normal subjects, where there was neither the additional secondary constriction nor the usual satellites.

In contrast to Böök et al. (1961), we found no abnormality in the 22 familial cases examined, though these included 14 instances of secundum atrial septal defect representing 9 different families.

In the single case of supravalve aortic stenosis with characteristic facies (Williams, Barratt-Boyes, and Lowe, 1961) the chromosomes were normal, unlike one of the cases reported by Palmer (1963) but in keeping with the other published findings (Eberle and Beuren, 1963; Palmer, 1963; Joseph, Polani, and Gold, 1963; de Grouchy and Emerit, 1963).

In conclusion, therefore, we consider it improbable that any of the variations reported are directly associated with congenital heart disease.

\section{SUMMARY}

No major chromosome abnormalities were found in a series of 156 patients with congenital heart disease. The modal count was 46 in each instance, and an increase in hypomodal cells with advancing age was noted. A few cells showed unstable structural abnormalities. Variations in size were observed in certain chromosomes, particularly number 16 . In two patients one of pair 16 was as large as a number 12, and in two others it resembled a 19; three of these four patients had an atrioventricular defect. In one patient with coarctation of the aorta a number 15 had particularly long short arms. The long 16 in one of the cases reported and the unusual chromosome 15 were shown to be inherited features. These results are discussed in relation to normal surveys and other instances where similar chromosomes have been reported.

We should like to express our gratitude to the Nuffield Foundation for supporting the Cytogenetics Laboratory at the Institute of Cardiology and to Professor P. E. Polani for his advice on the original organization. We are also indebted to Dr. W. M. Court Brown for his generous help with this paper and to the physicians of the National Heart Hospital for their co-operation.

\section{REFERENCES}

Anders, J. M., Moores, E. C., and Emanuel, R. (1965). Chromosome preparations from leucocyte culture: a simplified method for collecting cultures by post. J. med. Genet. In the press.

Böök, J. A., Santesson, B., and Zetterqvist, P. (1961). Association between congenital heart malformation and chromosomal variations. Acta paediat. (Uppsala), 50, 217.

Carr, D. H. (1963). Chromosomal abnormalities and their relation to disease. Canad. med. Ass. J., 88, 456.

Chandra, H. S., and Hungerford, D. A. (1963). An aberrant autosome (13-15) in a human female and her father, both apparently normal. Cytogenetics, $2,34$.

Court Brown, W. M., Mantle, D. J., Buckton, K. E., and Tough, I. M. (1964). Fertility in an XY/XXY male married to a translocation heterozygote. J. med. Genet., $1,35$.

Eberle, P., and Beuren, A. J. (1963). Chromosome studies in patients with supravalvular aortic stenosis. Lancet, 2, 438.

de Grouchy, J., and Emerit, I. (1963). Chromosome studies in patients with supravalvular aortic stenosis. Lancet, 2, 789.

Jacobs, P. A., Brunton, M., and Court Brown, W. M. (1964). Cytogenetic studies in leucocytes on the general population: subjects of ages 65 years and more. Ann. hum. Genet., 27, 353. ,- , Doll, R., and Goldstein, H. (1963). Change of human chromosome count distributions with age: evidence for a sex difference. Nature (Lond.), 197, 1080.

Jagiello, G., and Anders, J. M. (1965). In preparation.

Jennings, A. N., and Turner, B. (1961). Autosomal chromosome anomalies. Med. J. Aust., $2,830$.

Joseph, M. C., Anders, J. M., and Taylor, A. I. (1964). A boy with XXXXY sex chromosomes. J. med. Genet., 1, 95.

—, Polani, P. E., and Gold, R. G. (1963). Chromosome studies in patients with supravalvular aortic stenosis. Lancet, 2, 788 .

Kaiser, A., and Schmid, F. (1952). Die Herzfehlbildung beim Mongolismus. Münch. med. Wschr., $94,2167$.

Moorhead, P. S., Nowell, P. C., Mellman, W. J., Battips, D. M., and Hungerford, D. A. (1960). Chromosome preparations of leukocytes cultured from human peripheral blood. Exp. Cell Res., 20, 613. 
Palmer, C. G. (1963). Chromosome studies in patients with supravalvular aortic stenosis. Lancet, 2, 788.

Polani, P. E., Hunter, W. F., and Lennox, B. (1954). Chromosomal sex in Turner's syndrome with coarctation of the aorta. Lancet, $2,120$.

Rainier-Pope, C. R., Cunningham, R. D., Nadas, A. S., and Crigler, J. F., Jr. (1964). Cardiovascular malformations in Turner's syndrome. Pediatrics, 33, 919.

Rowe, R. D., and Uchida, I. A. (1961), Cardiac malformation in mongolism. Amer. J. Med., 31, 726.

Sasaki, M. S., Makino, S., and Kajii, T. (1963). Chromosomal aberrations in congenital cardiovascular disorders of man. Proc. Japan Acad., 39, 394.

Smith, D. W., Patau, K., Therman, E., Inhorn, S. L., and DeMars, R. I. (1963). The $D_{1}$ trisomy syndrome. J. Pediat., 62, 326.

Townes, P. L., Kreutner, K. A., Kreutner, A., and Manning, J. (1963). Observations on the pathology of the trisomy 17-18 syndrome. J. Pediat., 62, 703.

Williams, J. C. P., Barratt-Boyes, B. G., and Lowe, J. B. (1961). Supravalvular aortic stenosis. Circulation, 24, 1311. 